\author{
Agata Matysiak-BŁaszczyK \\ BARBARA JANKOWIAK \\ Uniwersytet im. Adama Mickiewicza \\ w Poznaniu
}

\title{
ZNACZENIE RELACJI PRZYWIĄZANIA \\ W CYKLU ŻYCIA CZŁOWIEKA. ANALIZA WYBRANYCH ASPEKTÓW BLISKICH RELACJI
}

\begin{abstract}
AвSTRAct. Matysiak-Błaszczyk Agata, Jankowiak Barbara, Znaczenie relacji przywiazania w cyklu życia człowieka. Analiza wybranych aspektów bliskich relacji [The Significance of the Attachment Relation in the Human Life Cycle. Analysis of Selected Aspects of Close Relations]. Studia Edukacyjne nr 44, 2017, Poznań 2017, pp. 195-208. Adam Mickiewicz University Press. ISSN 1233-6688. DOI: 10.14746/ se.2017.44.12

The article analyzes the significance of attachment relations for the ability to enter into close relations in the human life cycle. The secure attachment style which develops on the basis of the primordial relation between mother (or a guardian) and the child in the first stages of life is the cornerstone of future intimate relations and a resource which facilitates successful dealing with developmental tasks in interpersonal dependency relations. During the childhood, it contributes to the development of the relation of trust and dependence, during the adolescence to the growth of new extra-family relations and in adulthood to the co-creation with the partner of an intimate love relationship.
\end{abstract}

Key words: attachment styles, secure attachment style, dismissive-avoidant attachment style, anxious-preoccupied attachment style, fearful-avoidant attachment style, developmental tasks, close relations

\section{Wstęp}

John Bowlby, który stworzył koncepcję przywiązania, uważa, że relacja między dzieckiem i rodzicem odgrywa centralną rolę w rozwoju psychospołecznym dziecka ${ }^{1}$. Tworzenie więzi stanowi podstawę bliskich, intymnych relacji z innymi ludźmi, które są jednym z aspektów satysfakcjonującego życia społecznego. Umiejętność wchodzenia w relacje zależnościowe (a także prze-

${ }^{1}$ Zob. J. Holmes, J. Bowlby, Teoria przywiązania, przekł. J. Łaszcz, Gdańsk 2007. 
kształcanie tych relacji) jest kluczowa również dla możliwości realizacji zadań rozwojowych, które stawiane są przed jednostką w biegu jej życia. Zgodnie z założeniami poczynionymi przez R.J. Havighursta, poradzenie sobie z zadaniem rozwojowym prowadzi do stanu dobrego samopoczucia, zwiększonego poczucia własnej wartości i dobrego dostosowania w relacji między jednostką a jej kontekstem społecznym i stanowi podstawę skutecznego radzenia sobie z zadaniami rozwojowymi na przyszłych etapach życia², natomiast osoba, która nie poradzi sobie z zadaniem rozwojowym doświadcza braku satysfakcji i społecznej dezaprobaty ${ }^{3}$. W literaturze przedmiotu opisywane są badania wiążące styl przywiązania z ogólnym poczuciem dobrostanu4. Istnieją, więc przesłanki by sądzić, że style przywiązania są nie tylko kluczowe dla umiejętności budowania szczęśliwych związków, ale są także ważnym determinantem ogólnej jakości życia ${ }^{5}$. W tej pracy dokonano analizy literatury przedmiotu w celu sprawdzenia, jakie znaczenie w różnych etapach rozwoju ma styl przywiązania dla tworzenia bliskich związków z innymi osobami, a tym samym możliwości realizacji kolejnych zadań rozwojowych.

\section{Znaczenie więzi w rozwoju dziecka}

W procesie rozwoju i pierwotnej socjalizacji dziecka jego związek z matką (lub osobą sprawującą funkcje opiekuńcze) ma do odegrania szczególną rolę. Zachowania pierwszego opiekuna, jego obecność i bliskość relacji mają niebagatelny wpływ na całokształt rozwoju psychicznego i fizycznego dziec$\mathrm{ka}^{6}$. Zgodnie z psychospołeczną koncepcją rozwoju E. Eriksona, pierwszy kryzys rozwojowy, przypadający na okres od urodzenia do pierwszego roku życia dziecka, prowadzi do uzyskania fundamentalnego poczucia ufności do siebie i świata. O sposobie rozwiązania tegoż kryzysu, o jego rezultacie decydują przede wszystkim inni - dorośli, którzy poprzez swoją aktywność wprowadzają dziecko w obszar zaufania do siebie i świata lub do obszaru nieufności'. Według B.M. i P.R. Newmanów, jednym z podstawowych zadań rozwojowych tego okresu jest tworzenie społecznego przywiązania ${ }^{8}$. Mię-

\footnotetext{
${ }^{2}$ Havighurst, 1952, 1953, za: S. Bonino, E. Cattelino, S. Ciairano, Adolescents and Risk. Behavior, Functions, and Protective Factors, Italia 2005.

${ }^{3}$ B.M. Newman, P.R. Newman, Development through life: a psychosocial approach, California 1987, s. 30.

${ }^{4}$ Por. S. Moore, C. Leung, Young people's romantic attachment styles and their associations with well-being, Journal of Adolescence, 2002, 25, 2, s. 243-255.

${ }^{5}$ Zob. więcej: tamże; B. Jankowiak, Rodzinne i partnerskie uwarunkowania dobrostanu studentów, Studia Edukacyjne, 2016, 40, s. 177-190.

${ }^{6}$ J. Bowlby, Child Care and The Growth of Love, London 1953.

${ }^{7}$ E.H. Erikson, Dopetniony cykl życia, Poznań 2002.

${ }^{8}$ B.M. Newman, P.R. Newman, Development through life.
} 
dzy dzieckiem i matką w pierwszych latach życia wytwarza się więź, która dzięki rozszerzaniu się zasobu doświadczeń sensoryczno-emocjonalnych, w dalszej kolejności powoduje nasilenie związków emocjonalnych z ojcem, rodzeństwem, rówieśnikami i innymi osobami ${ }^{9}$. Pierwotny mechanizm przywiązania matki do dziecka ma ścisły związek z rozwojem więzi emocjonalnej, co słusznie podkreśla M. Bidzam. Zdaniem autorki, pierwotna więź matki i dziecka pojawia się w pierwszej kolejności jako wrodzona reakcja o charakterze autonomicznym, później powstają relacje emocjonalne dziecka z innymi ludźmi. Współcześnie pojęcie instynktu przekształciło się w pojęcie przywiązania, czy też więzi ${ }^{10}$. Więź oznacza łączność emocjonalną, która powstaje pomiędzy noworodkiem a opiekunem $w$ ciągu pierwszych dni życia dziecka ${ }^{11}$. W teorii przywiązania, której autorem jest J. Bowlby, opisane zostały cztery fazy kształtowania się więzi dziecka z opiekunem. W pierwszej fazie (od urodzenia do ok. ósmego - dwunastego tygodnia życia dziecka) nie rozróżnia ono osób znanych i obcych. Zachowanie dziecka kierowane jest w podobny sposób do wszystkich osób z otoczenia. Faza druga (od drugiego - trzeciego do szóstego - dziewiątego miesiąca) jest okresem, w którym niemowlę przyjaźnie reaguje na wszystkie osoby, jednak powoli coraz bardziej zaczyna odróżniać opiekunów od innych osób. Końcem tej fazy jest pojawienie się lęku przed osobami obcymi. W fazie trzeciej (od szóstego - dziewiątego miesiąca do końca drugiego roku życia) dziecko w toku rozwoju uczy się nowych zachowań przywiązaniowych, czyli służących utrzymywaniu bliskości z opiekunem. Wówczas kształtują się wzorce przywiązania z opiekunem. W czwartej fazie, która rozpoczyna się w trzecim roku życia, dziecko zaczyna uwzględniać nie tylko zachowania opiekuna, ale też jego plany, intencje i cele. Jest to faza otwarta. Rozumienie świata społecznego przez dziecko staje się coraz bardziej złożone ${ }^{12}$.

Mary Ainsworth na podstawie badań dotyczących relacji matka - dziecko, biorąc pod uwagę podstawowe kryterium jakości relacji jakim są: wrażliwość i dostępność matki w sytuacji zgłaszania przez dziecko potrzeb, wytypowała trzy style przywiązania: „styl bezpieczny - cechujący się zaufaniem dziecka do matki, oparty jest na doświadczeniu jego dostępności, ujawnianiu wrażliwości w sytuacjach zagrażających poczuciu komfortu, styl lękowo-ambiwalentny - kształtujący się w toku doświadczania niepewności co do dostępności obiektu przywiązania: kształtuje on wzmożoną czujność, obniżone

${ }^{9}$ M. Marczak, Petnienie roli matki przez kobiety pozbawione wolności, [w:] Misja Stużby Więziennej a jej zadania wobec aktualnej polityki karnej i oczekiwan społecznych, red. W. Ambrozik, H. Machel, P. Stępniak, Poznań - Gdańsk - Warszawa 2008, s. 458.

${ }^{10}$ L. Brannon, Psychologia rodzaju, przekł. M. Kacmajor, Gdańsk 2002, s. 251.

${ }^{11}$ Tamże, s. 252.

${ }^{12}$ D. Senator, Główne tezy teorii przywiązania, [w:] Bliskość w rodzinie. Więzi w dzieciństwie a zaburzenia w dorosłości, red. B. Tryjarska, Warszawa 2012, s. 36. 
poczucie bezpieczeństwa, silny lęk przed rozstaniem, pojawienie się w polu percepcyjnym obiektu przywiązania może wyzwalać ulgę, ale także i złość, styl unikający - kształtujący się w toku doświadczania niedostępności obiektu przywiązania w sytuacjach zagrożenia, wzbudzonej potrzeby bądź jego niewrażliwości na nie; doświadczenie to utrzymuje system przywiązania w stanie aktywnym, uruchamia mechanizmy obronne; konsekwencją może być unikanie bliskiego kontaktu - forma ochrony przed zranieniem; widoczna jest rezygnacja walki o obiekt przywiązania, a rozłąka nie musi się wiązać z przejawianiem negatywnych emocji"13.

Zachodni badacze na podstawie licznych wyników badań stwierdzają, że znaczenie przywiązania i poczucie bezpieczeństwa w relacjach matka-dziecko są uniwersalne kulturowo, a różnice międzykulturowe w klasyfikacjach przywiązania ilustrują, jak różne sposoby opieki nad dziećmi w różnych kulturach prowadzą do innego odsetka ufnie i lękowo przywiązanych dzieci ${ }^{14}$. Uniwersalnym faktem jest przekonanie, że rodzice na całym świecie pragną, by ich dzieci czuły się bezpiecznie w ich wzajemnych relacjach oraz to, że większość rodziców stara się promować cenione kulturowo formy poczucia bezpieczeństwa ${ }^{15}$. Badania wzorców przywiązania w różnych kulturach wskazują na konieczność uznania go za ważny pierwszy krok w nawiązywaniu stosunków z innymi ludźmi, mający moc definiowania wszystkich następujących po nim relacji ${ }^{16}$. Matka jest najważniejszą osobą w życiu każdego dziecka, odpowiedzialną za jego rozwój. Jakość więzi matki i dziecka jest bardzo istotna ${ }^{17}$.

Początkowo psychologowie badający rozwój przywiązania zakładali, że przywiązanie dziecka do matki jest wynikiem skojarzenia jej z zaspokajaniem takich podstawowych popędów, jak głód czy pragnienie. Obecność matki powiązana jest z obecnością pokarmu, w związku z czym matka staje się wzmocnieniem wtórnym wywołującym uczucie przyjemności ${ }^{18}$. Brak miłości macierzyńskiej wpływa na zaburzenia rozwoju psychicznego dziecka: instytucjonalizację dziecka, separację dziecka od matki lub osoby zastępującej tę matkę, "zwielokrotnienie" macierzyństwa oraz wypaczenie w opiece macierzyńskiej $^{19}$. Szczególnie niekorzystna dla rozwoju dzieci jest „deprywacja macierzyńska", czyli nieobecność matki we wczesnym dzieciństwie ${ }^{20}$. Bada-

${ }^{13}$ M. Karwowska, Macierzyństwo wobec dziecka niepetnosprawnego intelektualnie, Bydgoszcz 2007, s. 43-44.

${ }^{14}$ D.R. Schaffer, R. Kipp, Psychologia rozwojowa. Od dziecka do dorostości, Gdańsk 2015, s. 441.

${ }^{15}$ Tamże, s. 442.

${ }^{16}$ S.K. Ciccarelli, J.N. White, Psychologia, Poznań 2016, s. 321.

${ }^{17}$ M. Bidzan, Nastoletnie rodzicielstwo. Perspektywa psychologiczna, Gdańsk 2013, s. 141.

${ }^{18}$ Zob. badania psycholog H.F. Harlow, The nature of love, American Psychologist, 1958, 13, s. 573-685.

${ }^{19}$ K. Pospiszyl, Psychologia kobiety, Warszawa 1978, s. 134.

${ }^{20}$ K. Dzwonkowska-Godula, Tradycyjnie, czy nowocześnie? Wzory macierzyństwa i ojcostwa w Polsce, Łódź 2015, s. 60. 
nia nad wpływem instytucjonalizacji na rozwój dziecka mają bogatą tradycję. Wiele badań i obserwacji dzieci wychowywanych w warunkach pozbawienia prawidłowej i ciągłej opieki ze strony jednej bliskiej osoby wykazało w sposób jednoznaczny, że brak lub zerwanie bliskiego emocjonalnego związku dziecka z dorosłym powoduje głęboko negatywne, często nieodwracalne skutki dla rozwoju ${ }^{21}$.

Szczególny wkład do współczesnej wiedzy na temat rozwoju psychicznego jednostki opartej na teorii przywiązania wnieśli A. Sroufe, który stworzył koncepcję rozwoju emocjonalnego człowieka w pierwszych latach życia, P. Crittenden badający rozwój wzorców przywiązania w wieku przedszkolnym, M. Main rozwijająca badania różnych wzorców przywiązania oraz M. Rutter wyjaśniający skutki pozbawienia dzieci kontaktu z matką ${ }^{22}$. Zdaniem M. Czub, „jakość przywiązania i wynikające z tego konsekwencje dla rozwoju emocjonalnego człowieka w decydujący sposób wpływają na jego późniejsze funkcjonowanie emocjonalne i społeczne" ${ }^{23}$. O istotnym znaczeniu opieki macierzyńskiej w życiu każdego dziecka świadczą najlepiej przypadki tych dzieci, które z różnych względów zostały pozbawione opieki macierzyńskiej² . Jak wynika z badań R. Spitza, które prowadził na grupie dzieci przebywających w sierocińcu, a urodzonych w czasie pobytu matek w więzieniu, w wyniku braku bezpośredniego i stałego kontaktu u dzieci pojawił się zespół zaburzeń emocjonalnych, które nazwał chorobą sierocą ${ }^{25}$. Zdaniem wielu psychologów, stosunek emocjonalny do dziecka stanowi zasadniczą składową postawy dorosłego wobec dziecka i od tego uzależniony jest stopień zaspokojenia jego potrzeb, szczególnie potrzeby kontaktu i akceptacji - warunku poczucia bezpieczeństwa dziecka, a także jego aktywności, chęci poznawania i potrzeby osiągnięć. Pozytywne nastawienie matki wobec dziecka sprzyja kształtowaniu się poczucia własnej wartości dziecka ${ }^{26}$. W opinii M. Nowak-Dziemianowicz, „dzięki wzajemności rodzinnych relacji z innymi pojawia się oparty na uznaniu rodzaj samoodniesienia: wiara w siebie, poczucie własnej wartości, autonomia moralna i niezależność oraz

${ }^{21}$ M. Czub, Wiek niemowlęcy. Jak rozpoznać potencjat dziecka? [w:] Psychologiczne portrety człowieka. Praktyczna psychologia rozwojowa, red. A.I. Brzezińska, Gdańsk 2005, s. 49.

${ }^{22}$ M. Czub, Znaczenie wczesnych więzi spotecznych dla rozwoju emocjonalnego dziecka, Forum Oświatowe, 2003, 2(29), s. 32.

${ }^{23}$ Tamże.

${ }^{24}$ E. Adamska, M. Wawrzyk, D. Owsianka, Skazana matka w izolacji więziennej, [w:] Kobieta w więzieniu - polski system penitencjarny wobec kobiet w latach 1998-2008, red. I. Dybalska, Warszawa 2009, s. 243.

${ }^{25}$ K. Jankowski, Nie tylko dla rodziców, Warszawa 1983, s. 21-22.

${ }^{26}$ E. Napora, Cechy matek pożadane w wychowaniu dzieci, Problemy Rodziny, 1995, 1, s. 24 za: A. Matysiak-Błaszczyk, E. Włodarczyk, Macierzyństwo za kratami, Pedagogika Społeczna, 2004, 2-4. 
szacunek do samego siebie"27. W przypadku dzieci pozbawionych opieki matki mogą występować następujące zaburzenia: obniżenie odporności organizmu i zwiększenie zachorowalności (M. David), spowolnienie tempa przyrostu ciała (J. Fischoff i C.T. Whitten), płytkość uczuć, infantylizm uczuciowy, brak kontroli impulsów, stany dysforyczne (V. Nora), zaburzenia zachowania, autyzm (M. Eck), wykolejenie i nieprzystosowanie społeczne (J. Favez-Boutonier), ucieczki od rzeczywistości w świat wyobraźni i osobowości socjopatyczne (M. David), zaburzenia rozwoju umysłowego, zaburzenia rozwoju fizycznego ${ }^{28}$. Przywiązanie nadaje dziecku wielu niezbędnych wzmocnień. Dawcą ich jest matka. Ona - jako podstawowy i pierwszy opiekun - zaspokaja potrzeby biologiczne i psychiczne dziecka, przez co staje się dla dziecka obiektem szczególnym. Dziecko domaga się jej bliskości. Każde zachowanie matki zaspokajającej potrzeby fizyczne i potrzeby kontaktu stanowi pozytywne wzmocnienie zachowań dziecka. $Z$ kolei, dziecko uczy się tak dopasowywać swoje zachowania, aby uzyskać pożądane reakcje matki. Reagując na niektóre z nich, ona wzmacnia je i dzięki temu bardziej skuteczne $\mathrm{w}$ wywoływaniu pożądanych reakcji macierzyńskich zachowania (zwłaszcza zależne i afiliatywne) utrwalają się, a pozostałe nikną. Siła reakcji zależnościowych wiąże się z częstością stosowanych wzmocnień, ich rodzajem i rozkładem czasowym. Stopniowo obecność matki staje się źródłem odczuwalnych przyjemności, dlatego dziecko uspokaja się i reaguje pozytywnie na jej widok, natomiast jej brak wywołuje lęk i niepokój ${ }^{29}$. Relacja przywiązania między dzieckiem a matką staje się podstawą budowania innych satysfakcjonujących relacji, stanowi fundament, na którym budowane są możliwości realizacji kolejnych zadań rozwojowych oraz jest źródłem ochrony w kolejnych etapach życia. Kwestia czynników chroniących rozwój jest szeroko omawiana $\mathrm{w}$ koncepcjach resilience, w których wiele uwagi poświęca się czynnikom chroniącym o możliwościach modyfikowania skutków wysokiego ryzyka ${ }^{30}$. S.S. Luthar wśród najistotniejszych rodzinnych sił chroniących wymienia właśnie relację przywiązania ${ }^{31}$. Silne relacje rodzinne uważa się więc za krytyczne dla dobrego przystosowania w obliczu przeciwności losu.

${ }^{27}$ M. Nowak-Dziemianowicz, Walka o uznanie w narracjach. Jednostka i wspólnota w procesie poszukiwania tożsamości, Wrocław 2016, s. 165.

${ }^{28}$ Za: Z. Zaborowski, Koncepcja rozwoju społecznego dziecka, Kwartalnik Pedagogiczny, 1969, 1, za: A. Matysiak-Błaszczyk, E. Włodarczyk, Macierzyństwo za kratami.

${ }^{29}$ S. Lis, Proces socjalizacji dziecka w środowisku pozarodzinnym, Warszawa 1992, s. 17.

${ }^{30}$ B. Woynarowska, Edukacja zdrowotna - podstawy teoretyczne i metodyczne, [w:] Edukacja zdrowotna, red. B. Woynarowska, Warszawa 2013, s. 49.

${ }^{31}$ Zob. S.S. Luthar, Resilience in development: A synthesis of research across five decades, [w:] Developmental Psychopathology: Risk, disorder, and adaptation, red. D. Cicchetti, D.J. Cohen, New York 2006, s. 755-759. 


\section{Więź a funkcjonowanie w bliskich związkach w okresie adolescencji}

W okresie dorastania zaznacza się silna potrzeba niezależności. „Ważnym zadaniem jest uwolnienie się spod opieki i wpływu rodziców, a optymalnym efektem rozwoju w tej fazie powinno być ukształtowanie autonomicznej, spójnej osobowości" ${ }^{32}$. Powstaje więc pytanie: w jaki sposób przywiązanie do opiekuna wpływa na możliwość realizacji tego wyzwania? Ponieważ jednym z kluczowych zadań w tym okresie jest uzyskanie niezależności od rodziców i budowanie własnej autonomii, nastolatki wiele czasu poświęcają na kontakty rówieśnicze, poszukiwanie akceptacji przez rówieśników oraz uzyskiwanie pozycji wśród kolegów i koleżanek ${ }^{33}$. Psychologiczna autonomia obejmuje różne wymiary, w tym emocjonalną niezależność od dziecięcego uzależnienia od rodziców, behawioralną autonomię w zakresie samodzielnego funkcjonowania i autonomię poznawczą obejmującą zaufanie do siebie (pewność siebie) w podejmowaniu decyzji ${ }^{34}$. Osiągnięcie autonomii psychicznej nie oznacza jednak odrzucenia bliskiej relacji z rodzicami, wręcz przeciwnie - osiągnąć ją można poprzez utrzymanie pozytywnych relacji, które ulegają przekształceniom, zamiast poprzez odrzucenie rodziców ${ }^{35}$. G.W. Peterson i K. Ray Bush podkreślają, że pomimo wzrostu znaczenia w tym okresie czynników społecznych spoza rodziny, to nadal rodzina ma silny wpływ na rozwój młodzieży ${ }^{36}$. Zdaniem B.M. i P.R. Newmanów, wczesna faza dojrzewania charakteryzuje się zwiększoną wrażliwością na aprobatę rówieśniczą. Autorzy ci w odniesieniu do okresu wczesnej adolescencji przyjęli jako podstawowy kryzys - identyfikacja z grupą versus alienacja, dla etapu późnej adolescencji natomiast - tożsamość versus dyfuzja tożsamości. Zdaniem cytowanych autorów, dla młodszych adolescentów bardziej charakterystyczne jest poszukiwanie odpowiedzi na pytanie o ich relacje z grupą rówieśników, zanim odnajdą odpowiedź na pytanie na temat ich relacji z rodziną i stworzą własną tożsamość. Oznacza to, że młodzież najpierw rozwija poczucie

${ }^{32}$ M. Mary, H. Nordholt, Ukryty plan życia, Warszawa 2004, s. 29.

${ }^{33}$ M. Bardziejewska, Okres dorastania. Jak rozpoznać potencjat nastolatków? [w:] Psychologiczne portrety człowieka. Praktyczna psychologia rozwojowa, red. A.I. Brzezińska, Gdańsk 2015.

${ }^{34}$ W.A. Collins, T. Gleason, A. Sesma, Internalization, autonomy, and relationships: Development during adolescence, [w:] Parenting and children's internalization of values: A handbook of contemporary theory, red. J.E. Grusec, L. Kuczynski, New York 1995, s. 78-99.

${ }^{35}$ L.T. Steinberg, Interdependence in the family: Autonomy, conflict, and harmony in the parentadolescent relationship, [w:] At the threshold: The developing adolescent, red. S.S. Feldman, G.L. Elliott, Cambridge, MA 1990, s. 255-276.

${ }^{36}$ G.W. Peterson, K.R. Bush, Families and Adolescent Development, [w:] Handbook of Adolescent Behavioral Problems: Evidence-Based Approaches to Prevention and Treatment, red. T.P. Gullotta, R.W. Plant, M.A. Evans, New York 2015. 
tożsamości grupowej jako wstęp do rozwoju poczucia tożsamości indywidualnej ${ }^{37}$. Przyjaźń jest niezwykle ważna w sytuacji, gdy w rodzinie pochodzenia dochodzi do negatywnych zjawisk, na przykład przemocy. Istnieją dowody, że odporność (resilience) jest rzadka wśród dzieci doświadczających przemocy $\mathrm{w}$ rodzinie. $\mathrm{W}$ tym kontekście prowadzono badania wskazujące na znaczenie pozytywnych relacji z alternatywnymi osobami udzielającymi opieki i wsparcia jako przyczyniającymi się do zwiększenia szans na pozytywny rozwój. Na przykład, posiadanie odwzajemnionej relacji przyjacielskiej wiązało się ze wzrostem poczucia własnej wartości, co przyczyniało się do zmniejszenia poczucia samotności, zwiększenia spostrzeganej akceptacji, poprawy umiejętności społecznych oraz modyfikował się uaktualniany wzór przywiązania ${ }^{38}$.

Ponieważ normatywny kryzys wieku młodzieńczego jest ze względu na dużą labilność emocjonalną nastolatków doświadczany jako trudny ${ }^{39}$, młodzież podejmuje czasami ryzykowne zachowania jako sposób radzenia sobie z doświadczanymi problemami. Z prowadzonych badań wynika, że relacja przywiązania wpływa na wybory zachowań adaptacyjnych adolescentek i adolescentów. Na przykład, pozabezpieczne przywiązanie ${ }^{40}$ stanowi czynnik ryzyka zachowań przestępczych i agresji młodzieży.

Wyniki badań wskazują także na znaczenie więzi w kształtowaniu się zachowań seksualnych w okresie dorastania. Na ten okres życia przypada zazwyczaj pierwsza miłość oraz pierwsze doświadczenia seksualne ${ }^{41}$. Młodzi ludzie próbują ustalić $\mathrm{w}$ tym okresie właściwe relacje $\mathrm{z}$ otoczeniem, także w obszarze relacji seksualnych. Podejmują więc nowe zachowania seksualne, a także angażują się w relacje intymne. Nastolatki angażują się w coraz bardziej dojrzałe formy aktywności seksualnej - od masturbacji, poprzez petting, do inicjacji seksualnej ${ }^{42}$. Uzyskane wyniki dotyczące znaczenia stylu przywiązania $\mathrm{w}$ podejmowaniu ryzykownych zachowań seksualnych w okresie dojrzewania skłaniają do refleksji na temat wieloznaczności zachowań ryzykownych w rozwoju oraz ich znaczenia dla osiągnięcia znaczących celów

\footnotetext{
${ }^{37}$ B.M. Newman, P.R. Newman, Development through life, s. 320.

${ }^{38}$ S.S. Luthar, Resilience in development, s. 754.

${ }^{39}$ T.J. Wach, Profilaktyka i resocjalizacja nieletnich zagrożonych uzależnieniem od środków psychoaktywnych, Warszawa 2014, s. 173.

${ }^{40} \mathrm{M}$. Hoeve i in., A meta analysis of attachment to parents and delinquency, Journal of Abnormal Child Psychology, 2012, 40, s. 771-785; M.A. Zegers i in., Attachment and problem behavior of adolescents during residential treatment, Attachment and Human Development, 2008, 10, s. 91-103.

${ }^{41}$ I. Obuchowska, Adolescencja, [w:] Psychologia rozwoju człowieka. Charakterystyka okresów życia człowieka, t. 2, red. B. Harwas-Napierała, J. Trempała, Warszawa 2005, s. 163-202.

${ }^{42}$ Zob. M. Beisert, Dorastanie seksualne - pomost ku dorosłości, [w:] Psychologia rozwiazywania problemów szkoty, red. J. Miluska, Poznań 2001; taże, Trud dorastania seksualnego, [w:] Seksualność w cyklu życia człowieka, red. M. Beisert, Poznań 2004.
} 
rozwojowych ${ }^{43}$. Wyniki prowadzonych przez C. Lemelin, Y. Lussier, S. Sabourin, A. Brassard i Ch. Naud badań na grupie 1553 adolescentów i młodych dorosłych wykazały, że lękowe i unikowe reprezentacje przywiązania odgrywają ochronną rolę wobec młodzieńczych ryzykownych zachowań seksualnych. Młodzież o pozabezpiecznym stylu przywiązania jest mniej skłonna niż ich rówieśnicy o bezpiecznym stylu przywiązania do zaangażowania się we wczesne współżycie seksualne i posiadanie większej liczby partnerów ${ }^{44}$. Mimo że wyniki te mogą zaskakiwać, korespondują one z wcześniejszymi badaniami, które wykazały, że inicjacja seksualna często występuje w stałych związkach romantycznych ${ }^{45}$, a młodzież z unikowym przywiązaniem tworzy mniej liczne i mniej poważne romantyczne relacje ${ }^{46}$. $Z$ przedstawionych badań wynika, że młodzież charakteryzująca się bezpiecznym stylem przywiązania jest bardziej skłonna wcześniej niż ich rówieśnicy zawierać romantyczne związki oraz podejmować wcześniej aktywność seksualną, co z jednej strony wskazuje na szybsze osiąganie przez nich kolejnych zadań rozwojowych, lecz z drugiej naraża na ryzyko związane z podejmowaną aktywnością seksualną ${ }^{47}$.

\section{Więź w relacjach intymnych w okresie dorosłości}

Dorosłość jest etapem życia, w którym jednym z podstawowych zadań rozwojowych jest stworzenie związku intymnego z wybranym partnerem ${ }^{48}$. Warunkiem wejścia w etap budowania intymności w rozumieniu eriksonowskim jest osiągnięta tożsamość, a więc pozytywny bilans piątego normatywnego kryzysu rozwojowego. Związek intymny jest efektem pozytywnego rozwiązania kryzysu intymności oraz efektem świadomie i wolicjonalnie dokonanego wyboru o byciu z drugą osobą. Ponadto, partnerzy w związku intymnym nie są połączeni więzami krwi, zatem poczucie wzajemnej bliskości i więzi jest rezultatem ich wzajemnych deklaracji (decyzji) i prowadzi do

${ }^{43}$ Zob. więcej: B. Jankowiak, Zachowania ryzykowne wspótczesnej młodzieży. Studium teoretyczno-empiryczne, Poznań 2017.

${ }^{44}$ C. Lemelin i in., Risky sexual behaviours: The role of substance use, psychopathic traits, and attachment insecurity among adolescents and young adults in Quebec, The Canadian Journal of Human Sexuality, 2014, 23(3), s. 189-199.

${ }^{45}$ J.L. Rodgers, Sexual transition in adolescence, [w:] Transition through adolescence: Interpersonal domains and context, red. J.A. Graber, J. Brooks-Gunn, A.C. Peterson, New Yersey 1996, s. $85-110$.

${ }^{46}$ J.L. Tracy, Attachment styles and adolescent sexuality, [w:] Adolescent romance and sexual behavior: Theory, research, and practical implications, red. P. Florsheim, Mahwah, NJ 2003, s. 137-159.

${ }^{47}$ Zob. więcej: B. Jankowiak, Zachowania ryzykowne wspótczesnej młodzieży.

${ }^{48}$ B.M. Newman, P.R. Newman, Development through life. 
zobowiązań, nie zawsze mających swoje umocowanie instytucjonalne (np. w przypadku związków kohabitacyjnych) $)^{49}$.

W teoriach przywiązania poświęcono wiele miejsca na analizę konsekwencji określonych wzorców zależnościowych z matką i ojcem dla budowania w przyszłości relacji intymnej z partnerem. Styl przywiązania ukształtowany w dzieciństwie (na podstawie relacji dziecka z opiekunami) jest podobny do więzi utworzonych później z partnerami intymnymi ${ }^{50} \mathrm{i}$ wpływa na relacje o charakterze intymnym ${ }^{51}$. Badacze zauważyli nie tylko wspomniane podobieństwo w dynamice owych interakcji, ale też zaobserwowali trzy style przywiązania u osób dorosłych. Powielane interakcje z opiekunem rozwijają wewnętrzne modele, które w zmodyfikowanej postaci można zaobserwować w późniejszym życiu. W okresie dorosłości wpływają one głównie na sposób percepcji partnera i jego postawy, aktywność seksualną ${ }^{52}$, a nawet satysfakcję z małżeństwa - niższą wśród osób o pozabezpiecznym stylu przywiązania ${ }^{53}$.

Osoby o ukształtowanym bezpiecznym stylu przywiązania odczuwają satysfakcję ze związku z partnerem, wykazują akceptację i uznają wzajemne wsparcie w związku za ważne i potrzebne. Dorośli doświadczający bezpiecznego przywiązania, w tworzonych związkach pozytywnie wartościują wzajemną zależność, akceptują zachowania partnera, odczuwają radość z bliskich relacji. Uważają, że wsparcie bliskiej osoby jest potrzebne i dostępne. Dorośli, którzy doświadczyli w dzieciństwie stylu unikowego nie deklarują radości z bliskiego kontaktu z partnerem, mają trudności w zaufaniu mu i zaakceptowaniu swojej zależności. W związku z tym często podejmują zachowania manifestujące samowystarczalność i niezależność. Starania partnera, aby nastąpiło zbliżenie i zaangażowanie emocjonalne budzą w nich opór i zdenerwowanie. $W$ relacjach interpersonalnych osoby te są bardziej agresywne i skłonne do naruszania norm społeczno-prawnych, a innych ludzi opisują jako nieufnych. Jednostki z lękowo-ambiwalentnym wzorem przywiązania oceniają partnera jako mało zaangażowanego i wycofanego emocjonalnie, co

${ }^{49} \mathrm{~K}$. Kuryś-Szyncel, B. Jankowiak, Wspótczesne związki intymne - w poszukiwaniu nowych wzorców relacji, [w]: Role rodzinne. Między przystosowaniem a kreacja, red. I. Przybył, A. Żurek, Poznań 2016, s. 63-75.

${ }^{50}$ R.C. Fraley, P.R. Shaver, Adult romantic attachment: Theoretical developments, emerging controversies, and unanswered questions, Review of General Psychology, 2000, 4(2), s. 132-154; tychże, Airport Separations: A Naturalistic Study of Adult Attachment Dynamics in Separating Couple, Journal of Personality and Social Psycholog, 1998, 75, s. 1198-1210.

${ }^{51}$ R.C. Fraley, P.R. Shaver, Adult romantic attachment, s. 132-154; Dimension of Adult Attachment, Affects Regulation and Romantic Relationship Functioning, Personality and Social Psychology Bulletin, 1995, 21, s. 267-283.

${ }^{52}$ A. Gulczyńska, Rodzinne uwarunkowania aktywności seksualnej młodych dorosłych, Poznań 2009.

${ }^{53}$ M. Plopa, Więzi w matżeństwie i rodzinie. Metody badań, Kraków 2006. 
podnosi ich lęk o trwałość związku ${ }^{54}$. Badania prowadzone na grupie młodych kobiet potwierdziły korelację pomiędzy jakością aktualnie tworzonej relacji a stylami przywiązania. Kobiety o stylu bezpiecznym miały związki wyższej jakości niż te, które charakteryzował styl lękowo-ambiwalentny i unikowy ${ }^{55}$.

Wyniki prowadzonych badań na grupie młodych dorosłych (studentów) wykazały istnienie zależności pomiędzy stylami przywiązania charakterystycznymi dla badanych a jakością rzeczywistych związków oraz wyobrażeń o związkach spośród osób, które nie tworzą obecnie relacji intymnej (singli). Osoby o bezpiecznym stylu przywiązania uzyskiwały wysokie wyniki w ogólnej skali jakości związku oraz jej podskalach: wsparcia (przekonanie obojga partnerów, że mogą na siebie liczyć w ważnych sprawach, dbają o siebie, zaspokajają swoje potrzeby psychiczne, wykazują się zrozumieniem i wzajemnym wsparciem), namiętności (poczucie atrakcyjności seksualnej partnerów, satysfakcjonująca aktywność seksualna w związku) i odpowiedzialności za związek (wzajemne zaufanie, lojalność, wierność). Uzyskano także ujemne korelacje pomiędzy stylem unikowym i lękowo-ambiwalentnym a jakością związków - ogólną oraz we wszystkich badanych wymiarach. Oznacza to, że osoby, które charakteryzują te style przywiązania doświadczają trudności w tworzeniu satysfakcjonujących relacji intymnych. Wśród singli - osoby o bezpiecznym stylu przywiązania są przekonane, że są w stanie stworzyć związek wysokiej jakości, charakteryzujący się wysokim poziomem satysfakcji seksualnej, zaufaniem, lojalnością, zrozumieniem i wsparciem. Unikowy styl przywiązania singli ujemnie koreluje z ogólną jakością wyobrażeń o związkach oraz z wymiarami wsparcia i namiętności. Oznacza to, że osoby o unikowym stylu przywiązania zakładają, że będą doświadczać trudności we wchodzeniu w relacje - ich wyobrażenia o satysfakcji seksualnej oraz możliwości zaspokajania innych ważnych potrzeb w związku z inną osobą są niższe niż u osób o innym typie przywiązania ${ }^{56}$.

Bezpieczny styl przywiązania kształtujący się na bazie pierwotnego związku między matką (lub osobą sprawującą funkcje opiekuńcze) a dzieckiem w pierwszych etapach życia stanowi bazę kształtowania się późniejszych bliskich relacji. Jest zasobem umożliwiającym pozytywne radzenie sobie z zadaniami rozwojowymi $\mathrm{w}$ biegu życia człowieka. $\mathrm{W}$ dzieciństwie

${ }^{54}$ C. Hazan, P. Shaver, Romantic love conceptualized as an attachment process, Journal of Personality and Social Psychology, 1987, 52, s. 511-524; R.C. Fraley, P.R. Shaver, Adult romantic attachment, s. 132-154.

${ }^{55}$ A. Gulczyńska, B. Jankowiak, Style przywiazania a funkcjonowanie w zwiazkach partnerskich młodych kobiet. Analiza wyników badań własnych, [w:] Rodzina - młodzież - dziecko. Szkice z teorii praktyki pomocy psychopedagogicznej i socjalnej, red. M. Piorunek, J. Kozielska, A. Skowrońska-Pućka, Poznań 2013.

${ }^{56}$ B. Jankowiak, Związi partnerskie studentów. Jakość i trwałość a elementy struktury formalnej oraz uwarunkowania rodzinne relacji intymnych, Studia Edukacyjne, 2015, 35, s. 215-233. 
przyczynia się do kształtowania relacji ufności i zależności, w adolescencji - do budowania nowych pozarodzinnych relacji (choć przyczynia się także do szybszego wchodzenia $w$ relacje seksualne, co z jednej strony świadczy o rozwoju relacji w parze, lecz z drugiej staje się zagrożeniem), a w dorosłości stanowi bazę, na której można budować miłosną relację intymną z partnerem życiowym.

\section{BIBLIOGRAFIA}

Adamska E., Wawrzyk M., Owsianka D., Skazana matka w izolacji więziennej, [w:] Kobieta w więzieniu - polski system penitencjarny wobec kobiet w latach 1998-2008, red. I. Dybalska, Warszawa 2009.

Bardziejewska M., Okres dorastania. Jak rozpoznać potencjał nastolatków? [w:] Psychologiczne portrety człowieka. Praktyczna psychologia rozwojowa, red. A.I. Brzezińska, Gdańsk 2015.

Beisert M., Dorastanie seksualne - pomost ku dorostości, [w:] Psychologia rozwiązywania problemów szkoły, red. J. Miluska, Poznań 2001.

Beisert M., Trud dorastania seksualnego, [w:] Seksualność w cyklu życia człowieka, red. M. Beisert, Poznań 2004.

Bidzan M., Nastoletnie rodzicielstwo. Perspektywa psychologiczna, Gdańsk 2013.

Bowlby J., Child Care and The Growth of Love, London 1953.

Brannon L., Psychologia rodzaju, przekł. M. Kacmajor, Gdańsk 2002.

Brennan K.A., Shaver P.P., Dimension of Adult Attachment, Affects Regulation and Romantic Relationship Functioning, Personality and Social Psychology Bulletin, 1995, 21.

Ciccarelli S.K., White J.N., Psychologia, Poznań 2016.

Collins W.A., Gleason T., Sesma A., Internalization, autonomy, and relationships: Development during adolescence, [w:] Parenting and children's internalization of values: A handbook of contemporary theory, red. J.E. Grusec, L. Kuczynski, New York 1995.

Czub M., Znaczenie wczesnych więzi spotecznych dla rozwoju emocjonalnego dziecka, Forum Oświatowe, 2003, 2(29), s. 32.

Czub M., Wiek niemowlęcy. Jak rozpoznać potencjał dziecka? [w:] Psychologiczne portrety człowieka. Praktyczna psychologia rozwojowa, red. A.I. Brzezińska, Gdańsk 2005.

Dzwonkowska-Godula K., Tradycyjnie, czy nowocześnie? Wzory macierzyństwa i ojcostwa w Polsce, Łódź 2015.

Erikson E.H., Dopetniony cykl życia, Poznań 2002.

Fraley R.C., Shaver P.R., Airport Separations: A Naturalistic Study of Adult Attachment Dynamics in Separating Couple, Journal of Personality and Social Psycholog, 1998, 75.

Fraley R.C., Shaver P.R., Adult romantic attachment: Theoretical developments, emerging controversies, and unanswered questions, Review of General Psychology, 2000, 4(2).

Gulczyńska A., Rodzinne uwarunkowania aktywności seksualnej młodych dorostych, Poznań 2009.

Gulczyńska A., Jankowiak B., Style przywiazania a funkcjonowanie w zwiazkach partnerskich młodych kobiet. Analiza wyników badań własnych, [w:] Rodzina - młodzież - dziecko. Szkice $z$ teorii praktyki pomocy psychopedagogicznej i socjalnej, red. M. Piorunek, J. Kozielska, A. Skowrońska-Pućka, Poznań 2013.

Harlow H.F., The nature of love, American Psychologist, 1958, 13.

Havighurst R.J., Human development and education, New York 1953. 
Havighurst, 1952, 1953, za: S. Bonino, E. Cattelino, S. Ciairano, Adolescents and Risk. Behavior, Functions, and Protective Factors, Italia 2005.

Hazan C., Shaver P., Romantic love conceptualized as an attachment process, Journal of Personality and Social Psychology, 1987, 52.

Hoeve M., Stams G.J.J., Van Der Put C.E., Dubas J.S., van der Laan P.H., Gerris J.R., A meta analysis of attachment to parents and delinquency, Journal of Abnormal Child Psychology, 2012, 40.

Holmes J., Bowlby J., Teoria przywiązania, przekł. J. Łaszcz, Gdańsk 2007.

Jankowiak B., Związki partnerskie studentów. Jakość i trwatość a elementy struktury formalnej oraz uwarunkowania rodzinne relacji intymnych, Studia Edukacyjne, 2015, 35.

Jankowiak B., Rodzinne i partnerskie uwarunkowania dobrostanu studentów, Studia Edukacyjne, 2016, 40.

Jankowiak B., Zachowania ryzykowne wspótczesnej młodzieży. Studium teoretyczno-empiryczne, Poznań 2017.

Jankowski K., Nie tylko dla rodziców, Warszawa 1983.

Karwowska M., Macierzyństwo wobec dziecka niepetnosprawnego intelektualnie, Bydgoszcz 2007.

Kuryś-Szyncel K., Jankowiak B., Wspótczesne związki intymne - w poszukiwaniu nowych wzorców relacji, [w]: Role rodzinne. Między przystosowaniem a kreacją, red. I. Przybył, A. Żurek, Poznań 2016.

Lemelin C., Lussier Y., Sabourin S., Brassard A., Naud C., Risky sexual behaviours: The role of substance use, psychopathic traits, and attachment insecurity among adolescents and young adults in Quebec, The Canadian Journal of Human Sexuality, 2014, 23(3).

Lis S., Proces socjalizacji dziecka w środowisku pozarodzinnym, Warszawa 1992.

Luthar S.S., Resilience in development: A synthesis of research across five decades, [w:] Developmental Psychopathology: Risk, disorder, and adaptation, red. D. Cicchetti, D.J. Cohen, New York 2006.

Marczak M., Petnienie roli matki przez kobiety pozbawione wolności, [w:] Misja Stużby Więziennej a jej zadania wobec aktualnej polityki karnej i oczekiwań społecznych, red. W. Ambrozik, H. Machel, P. Stępniak, IV Polski Kongres Penitencjarny, Poznań - Gdańsk - Warszawa 2008.

Mary M., Nordholt H., Ukryty plan życia, Warszawa 2004.

Matysiak-Błaszczyk A., Włodarczyk E., Macierzyństwo za kratami, Pedagogika Społeczna, 2004, 2-4.

Moore S., Leung C., Young people's romantic attachment styles and their associations with well-being, Journal of Adolescence, 2002, 25, 2.

Napora E., Cechy matek pożądane w wychowaniu dzieci, Problemy Rodziny, 1995, 1.

Newman B.M., Newman P.R., Development through life: a psychosocial approach, California 1987.

Nowak-Dziemianowicz M., Walka o uznanie w narracjach. Jednostka i wspólnota w procesie poszukiwania tożsamości, Wrocław 2016.

Obuchowska I., Adolescencja, [w:] Psychologia rozwoju człowieka. Charakterystyka okresów życia człowieka, t. 2, red. B. Harwas-Napierała, J. Trempała, Warszawa 2005.

Peterson G.W., Bush K.R., Families and Adolescent Development, [w:] Handbook of Adolescent Behavioral Problems: Evidence-Based Approaches to Prevention and Treatment, red. T.P. Gullotta, R.W. Plant, M.A. Evans, New York 2015.

Plopa M., Więzi w małżeństwie i rodzinie. Metody badań, Kraków 2006.

Pospiszyl K., Psychologia kobiety, Warszawa 1978. 
Rodgers J.L., Sexual transition in adolescence, [w:] Transition through adolescence: Interpersonal domains and context, red. J.A. Graber, J. Brooks-Gunn, A.C. Peterson, New Yersey 1996.

Schaffer D.R., Kipp R., Psychologia rozwojowa. Od dziecka do dorosłości, Gdańsk 2015.

Senator D., Główne tezy teorii przywiazania, [w:] Bliskość w rodzinie. Więzi w dzieciństwie a zaburzenia w dorostości, red. B. Tryjarska, Warszawa 2012.

Steinberg L.T., Interdependence in the family: Autonomy, conflict, and harmony in the parentadolescent relationship, [w:] At the threshold: The developing adolescent, red. S.S. Feldman, G.L. Elliott, Cambridge, MA 1990.

Tracy J.L., Shaver P.R., Albino A.W., Cooper M.L., Attachment styles and adolescent sexuality, [w:] Adolescent romance and sexual behavior: Theory, research, and practical implications, red. P. Florsheim, Mahwah, NJ 2003.

Wach T.J., Profilaktyka i resocjalizacja nieletnich zagrożonych uzależnieniem od środków psychoaktywnych, Warszawa 2014.

Woynarowska B., Edukacja zdrowotna - podstawy teoretyczne i metodyczne, [w:] Edukacja zdrowotna, red. B. Woynarowska, Warszawa 2013.

Zaborowski Z., Koncepcja rozwoju społecznego dziecka, Kwartalnik Pedagogiczny, 1969, 1.

Zegers M.A., Schuengel C., Van IJzendoorn M.H., Janssens J.M., Attachment and problem behavior of adolescents during residential treatment, Attachment and Human Development, 2008,10 . 